\title{
Labor Markets and Social Security in the Entrepreneurial Society
}

\subsection{General Principles}

A necessary condition for the long-term success of a new venture is that the entrepreneur can recruit key personnel at the opportune time to scale up the business to a full-grown firm (Eliasson 1996; Elert and Henrekson 2019). While new ventures are free to offer jobs and recruit workers as they see fit, they do not compete for the talent they need on a level playing field. Unlike other inputs in the production process, employing labor typically comes with responsibilities that go beyond paying a competitive wage-responsibilities that may be particularly hard for new ventures to shoulder. Such issues make access to key personnel more constrained than it need be, to the detriment of the workings of collaborative innovation blocs.

Because labor is a critical input in all economic activities, we propose neutrality as a first principle to guide reforms in this area. In this context, the neutrality principle refers to equal access, i.e., that employers can compete for workers and employees can compete for jobs based on the relevant characteristics of the job and the potential recruits. Moreover, employees should be free to move from one job to the next, just as employers should be free to adjust the labor force to the needs of their venture (subject to rules guaranteeing that any dismissal of redundant or allegedly underperforming workers follows a fair and transparent procedure). Only when both sides have this flexibility can the matching in labor markets promote an entrepreneurial society.

As labor constitutes the primary source of income in a market-based economy, it is not surprising that employees greatly value security, stability, and equitable distribution. While these values are valid, they also imply that an 
efficient labor market matching of the kind just envisioned is far from the most important criterion used by Europeans to assess labor markets and social security institutions. When proposing reforms to labor and social security arrangements, we must carefully weigh and balance these values so that our proposals conform to the principle of justifiability.

Carefully separating individual and collective responsibilities is the best way to achieve this balance. Basic social security is a collective responsibility best organized through moderate universal arrangements that do not unduly reduce flexibility for employers or mobility for employees. Individual employers will then reward merit, and employees will invest in talent, ensuring a reasonably efficient wage structure that is also fair. ${ }^{1}$ If enacted, the proposed reforms would increase the mobility of workers and flexibility for employers by removing onerous labor market regulations while providing the social security system with much needed risk pooling for the risks all individuals face but cannot manage individually.

The incentives that encourage activation, mobility, and risk-taking are best served by universal insurance systems that disregard labor market status, history, or attachment. These institutions should, therefore, ensure portability of tenure rights and pension plans as well as a full decoupling of health insurance from current employers. Such measures would avoid punishing individuals who leave secure, tenured employment positions and pursue entrepreneurial projects, whether as entrepreneurs or as employees in entrepreneurial startups. Finally, the extent to which these risks are collectively insured should be moderate, and systems should be kept simple to achieve the salience necessary for people to act rationally and avoid costs from spiraling out of control.

The EU has limited competencies for implementing reforms pertaining to labor markets and social security systems, which is logical given that the same reforms can be expected to work out quite differently in different contexts. ${ }^{2}$ Thus, we primarily address the following proposals to the member states (cf. Suse and Hachez 2017, p. 49).

\footnotetext{
${ }^{1}$ To be sure, what is considered fair is highly context dependent and remains an open question (e.g., Binmore 2005). We propose here that a fair income distribution enables everyone to have a universal social minimum living standard while rewarding people for effort and merit. Ultimately, these outcomes result from ongoing political and bargaining processes, which, in turn, depend on productivity differences emerging across the labor market. In this chapter, we focus on ways to make portable those claims, benefits, and services that are best provided universally, such that these considerations do not drive and bias the allocation of labor.

${ }^{2}$ Here, the only legislative competencies in the treaties are those intended to ensure mobility of worker rights across member states (e.g., Article 153(2)(b) TFEU). In practice, this may give the Union some legislative power because rights that are not portable across employers are often also not portable across national borders.
} 


\subsection{Proposals}

We begin this section by presenting our analysis and proposals relating to employment protection regulations. This is followed by our analysis and proposals with respect to social security.

\subsubsection{Employment Protection Legislation}

Figure 5.1 shows the stringency of employment protection legislation (EPL) in the EU countries and the USA for temporary and permanent contracts. While the Anglo-Saxon countries have the least stringent employment protection by far within the EU, most other countries have liberalized their legislation for temporary employment considerably in recent decades (Skedinger 2010; Martin and Scarpetta 2012). Sweden and Germany stand out for their substantial liberalization of temporary contracts over the past 20 years; notably, these are two of the top-performing EU countries in terms of employment. Arguably, this has to do with their high shares of temporary employment

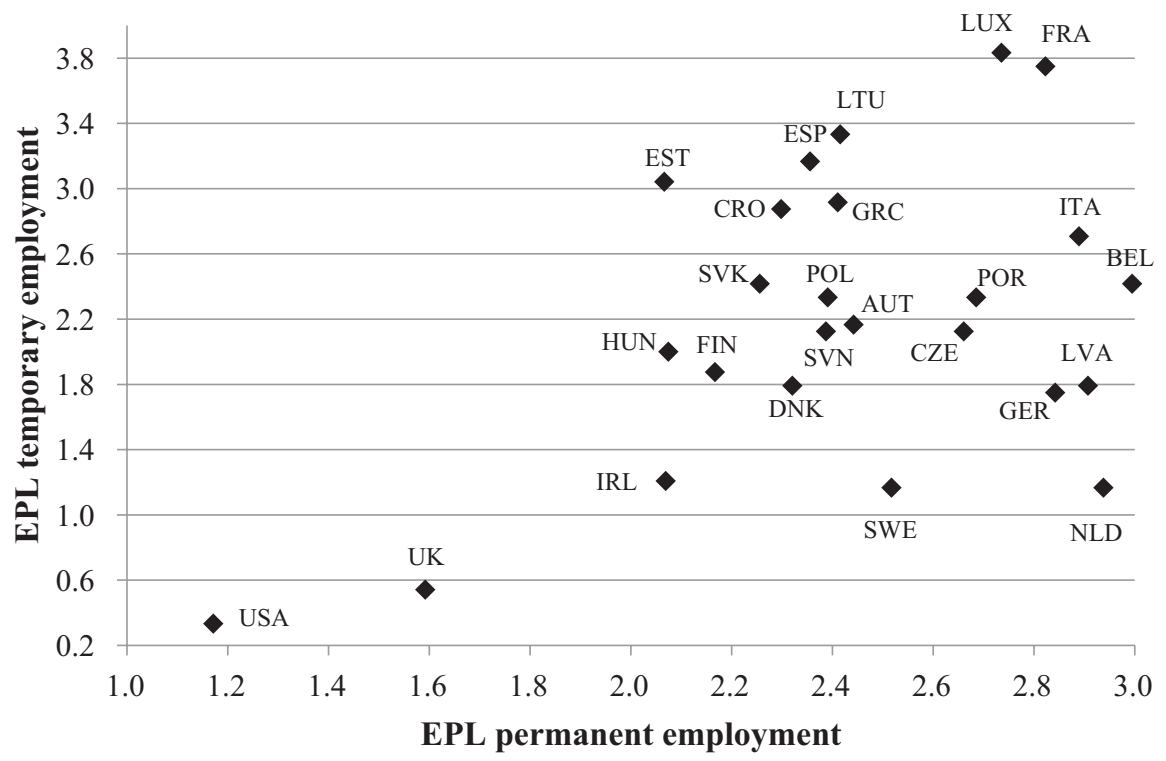

Fig. 5.1 Stringency of employment protection legislation for workers on permanent and temporary contracts in EU countries and the USA, 2013. Note: The scale of the index is 0-6, where 6 represents the most stringent regulation. 2013 is the latest available year. The index for permanent employment is the index for individual and collective dismissals. Source: OECD/IAB Employment Protection Database, 2013 
(OECD 2016a). In 2017, employment through temporary contracts constituted 22.2 and $13.8 \%$ of total employment in Germany and Sweden, respectively (OECD 2019b). ${ }^{3}$

Figure 5.1 also reveals considerable gaps between temporary and permanent employment; for example, the Netherlands ranks 2nd for permanent and 26th for temporary contract protection out of 33 OECD countries (OECD 2013). Such discrepancies may have some logic to them: policymakers may see tight labor protection for permanent employees as necessary to maintain high levels of firm-specific human capital (Adnett et al. 2004) yet prefer temporary work over unemployment when it serves as a stepping stone to permanent contracts (Scherer 2004; Gash 2008). Nonetheless, the widening gap has caused concern about the emergence of dual labor markets (Gebel 2010; Hirsch 2016a; Dolado 2016). While it is true that this constellation allows employers to retain a fixed core of competencies while adjusting the size of their labor force to demand fluctuations at low costs, the productivity of the jobs created remains low (Kleinknecht et al. 2006). Moreover, the disparity implies that government-enforced regulation tilts the playing field against entrepreneurial ventures: the greater the disparity between temporary and permanent contracts, the greater the opportunity cost for an employee on a permanent contract of accepting a job in a high-risk firm.

Interestingly, all Eastern European countries have increased the stringency of their legislation related to temporary contracts. Without implying direct and strong causality here, we take note of their generally weak employment performance, especially among the more populous Eastern European member states Poland and Romania (see Fig. 1.1). Overall, legislation concerning both types of contracts remains strict in most Mediterranean and Continental European countries.

To mitigate the adverse effects of overly stringent EPL, policymakers in many European countries have instituted firm-size thresholds below which regulations are more relaxed. In practice, however, the threshold is the equivalent of a tax on firm growth and has been shown to incentivize firms to remain small in, e.g., Germany (Autio et al. 2007), France (Garicano et al. 2016), Portugal (Braguinsky et al. 2011), and Italy (Schivardi and Torrini 2008). Discouraged by such thresholds, many entrepreneurs never discover whether they could have become high-impact entrepreneurs. More generally, there is a

\footnotetext{
${ }^{3}$ In the absence of controlled experiments it is hard to firmly establish causality from such correlations and some have suggested alternative explanations for the data (e.g., Kahn 2009). Germany also allowed for wider wage dispersion and Sweden implemented several other reforms as well. These changes may have contributed to employment growth in these countries.
} 
negative relationship between the overall strictness of EPL and the rate of high-growth expectation early-stage entrepreneurship (the percentage of individuals engaged in entrepreneurial activity who expect their firms to grow to employ at least five employees within 5 years), as seen in Fig. 5.2.

If the $\mathrm{EU}$ is to become more inclusive, innovative, and entrepreneurial, its most regulated countries should reduce the stringency of their EPL for permanent contracts. Competently implemented liberalization would reduce job security but increase employment security for workers because it would increase labor demand and result in the creation of more labor market opportunities.

Proposal 23: Relax the stringency of employment protection legislation for permanent contracts.

That said, the impact and strictness of EPL depend on a complex combination of components, such as grounds for individual dismissal, redundancy procedures, mandated periods of advanced notice, severance payments, special

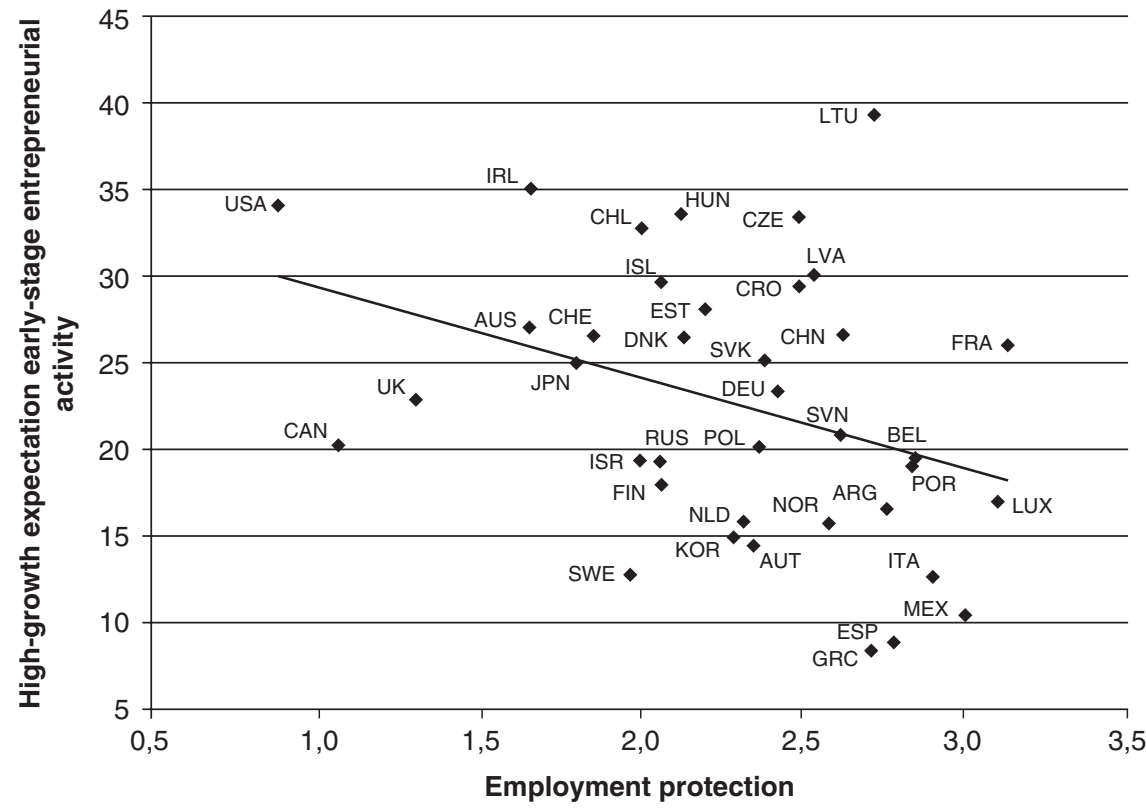

Fig. 5.2 The strictness of employment protection, 2013, and high-growth expectation early-stage entrepreneurial activity, 2015-2018. Note: High-growth expectation earlystage entrepreneurial activity is averaged over the 4 years 2015-2018. Permanent EPL is given a weight of $2 / 3$ and temporary EPL a weight of $1 / 3$. Sources: Global Entrepreneurship Monitor and OECD/IAB Employment Protection Database, 2013 update 
requirements for collective dismissals, and rules favoring disadvantaged groups. For liberalization to produce the desired results, countries must consider and possibly emulate the paths already explored in similar countries. As we shall argue below, such a strategy also presupposes the implementation of complementary social insurance institutions.

A relatively simple way for policymakers to make the labor supply more flexible and responsive to the needs of entrepreneurs would be to give workers and employers more freedom to contract on working hours. Such freedom should apply to weekly and daily hours, holiday, overtime, and irregular hours, for which the EU and its member states have implemented detailed and stringent minimum standards (e.g., European Union 2018b; Messenger et al. 2007).

Proposal 24: Allow for more flexibility in working hours by reconsidering overly stringent minimum requirements for daily and weekly working hours, holidays, irregular hours, and overtime.

Policymakers should also strive to promote worker mobility across jobs, industries, and regions. Notably, confidentiality agreements and non-compete clauses often prevent knowledge from flowing freely between firms and sectors. The fact that non-compete clauses are not allowed in California (as opposed to, say, Texas) is seen as an important element in the development of the golden state's highly successful entrepreneurial ecosystem (Gilson 1999). ${ }^{4}$

Proposal 25: Lift the legal enforceability of confidentiality agreements between employers and their employees.

Finally, it would be beneficial to reduce job tenure-related wage scales and severance pay; these insider benefits tend to lock people into their current job and shift bargaining power in the labor market to large, incumbent employers (Lindbeck and Snower 2001; Eichhorst et al. 2017). However, before employment protection and job security can be reformed, it is wise to put in place a social security system that empowers (all) workers vis-à-vis their employers by creating a robust fallback option.

\footnotetext{
${ }^{4}$ Marx et al. (2009) further highlight the importance of non-compete clauses: Examining Michigan's 1985 reversal of its non-compete enforcement policy, they find that this weakened worker mobility, especially for inventors with firm-specific skills and specialists in narrow technical fields.
} 


\subsubsection{Social Insurance Systems}

In principle, providing insurance for the usual social risks (loss of income due to unemployment, illness, disability or old age, and high medical, child care, or educational expenses) enables individuals to consider and pursue entrepreneurial endeavors by mitigating the burden of uncertainty. Social security systems still vary a great deal across Europe, ${ }^{5}$ but the design features of these systems are more relevant than their overall levels and generosity. As Sinn (1996) argues, when insurance is closely linked to tenure in a specific job, it does not promote an entrepreneurial spirit. What matters for the individual is the opportunity cost, i.e., how much an employee who transfers to selfemployment or a risky job in an entrepreneurial firm has to sacrifice in terms of income and security. If there are no public or collective insurance schemes, these costs can be prohibitive. Company-specific health insurance plans, as are common in the USA, are an obvious example; another is accumulated pension assets that are difficult to transfer when switching employers, industries, or countries of residence. If policymakers decoupled these and other benefits from the current employer-employee relationship, they would increase labor mobility and eliminate the competitive advantage held by large mature companies in attracting and retaining talent.

Proposal 26: Guarantee equal access to welfare state arrangements for all, regardless of tenure in a specific job or labor market status.

An important role model in this respect can be Denmark's flexicurity system, which combines generous welfare protection and opportunities for retraining with weak job security mandates (Andersen 2005). Danish employees lose little when they switch employers or labor market status, making Danish talent available on equal terms for entrepreneurial firms (Bredgaard 2013). By contrast, a Swedish employee who voluntarily gives up a tenured position for self-employment typically has no more security than what is provided by (means-tested) social welfare. Thus, the opportunity cost of giving up a tenured position in Denmark is substantially lower than in Sweden.

EU member states should embrace the general principles of flexicurity, which can be summarized as flexible and reliable contractual arrangements, comprehensive lifelong learning strategies, effective active labor market

\footnotetext{
${ }^{5}$ As shown in Fig. A.2 in the Appendix, replacement rates for unemployment insurance, for example, vary a great deal among European countries. It should also be noted that irrespective of duration and family constellations the USA is invariably found at or close to the bottom of the ranking.
} 
policies, and modern social security systems providing adequate income support during transitions (European Commission 2007). However, while the general principles of flexicurity are almost invariably met with approval by policymakers at the EU level, the devil is in the details: member states should carefully consider the impact of flexicurity reforms on young SMEs. We stress this last point as it is politically convenient and often tempting for policymakers to shift the burden of administration and risks in lifelong learning strategies onto employers, whether through sectoral training funds or by giving employers the responsibility to invest in the employability of their workers (Vermeylen 2008; Verdier 2009). Unions will push for such measures on behalf of their members, while large firms will typically not resist them. However, such responsibilities are more burdensome for small employers and it is better to leave such responsibilities with the employee when this is possible and collectivize them at the sectoral or national level where necessary. As small and especially not-yet-existing employers have a harder time lobbying for their joint interests, politicians must resist the tendency to make individual employers responsible for the employability of their workers. Flexicurity reforms should decouple the protection of employees from their employer so as not to tilt the playing field more against entrepreneurial ventures.

Proposal 27: Carefully consider the impact of flexicurity reforms on young firms and do not force them to take on excessive risks and burdens.

Behavioral biases are known to cause adverse selection and the underinsurance of risks. Basic risks in the labor market are therefore best covered by collective and mandatory insurance, ensuring that employees do not compete on social insurance coverage in a race to the bottom. That said, employers should be allowed to offer complementary pension plans as long as the accumulated assets are fully portable when employees switch employers or become self-employed.

Proposal 28: Introduce mandatory universal insurance to cover healthcare costs, old age, and disability.

Making such insurance mandatory prevents adverse selection problems; making them universal prevents unproductive compartmentalization in the labor market and ensures full portability of entitlements. The Dutch system for health care costs may be a role model here: though mandatory, it allows insurance companies to compete for patients (Maarse et al. 2016). Crucially, the design of such systems should ensure that competition focuses on price and avoids causing a race to the bottom in quality or coverage. In the Dutch 
case, detailed product specifications are set by law, and insurers must accept all patients. However, they can and do compete on brand loyalty; although $4-7 \%$ of consumers indicate that they intend to switch providers every year, fewer turn this intention into reality (Schut et al. 2013). As a result, insurers can extract significant rents from the human tendency to prefer the status quo. Employers collectively bargaining on behalf of their employees have even created a closer link between current employment and health benefits than existed previously. ${ }^{6}$ Possibly, allowing insurance companies to bid for collective blocks of insurance policies would lessen the need to advertise, whereas adequately designed closed-bid auctions may keep prices and costs at a reasonably low level.

A core aim in this reform area should be to make the individual's social benefits independent of tenure at an employer-regardless of whether the insurance is public, paid by the individual herself, or paid by the employer based on individual or collective agreement. Tenure often plays a role in unemployment benefit entitlements and disability insurance. Unemployment benefits insure against the involuntary loss of income, but when someone switches into or out of self-employment or between jobs, the counter is often reset, reducing both the duration and the benefit level in the case of a new unemployment spell. With disability, benefits are often made dependent on the level of income and tenure in the job held at the time the disability occurs; the risk of losing these entitlements prevents beneficiaries from moving into other occupations or sectors.

One example of how to achieve full portability is the Austrian reform of 2003, which converted uncertain firing costs for employers into a system of individual savings accounts funded by a payroll tax (Hofer 2007). The system guarantees the employer who hires someone certainty about the cost of any future dismissal, while workers do not lose their entitlement to severance pay should they decide to quit and take a new job. Similar measures could also make unemployment benefit entitlements and disability insurance portable.

Proposal 29: Ensure full portability of social security entitlements by making them independent of tenure at a specific employer.

This proposal is highly relevant for a country such as Germany, where labor market mobility is low, geographically (Niebuhr et al. 2012; Bentivogli and Pagano 1999), occupationally (Korpi and Mertens 2003; König and Müller

${ }^{6}$ These collective policies on average are between 3 and $10 \%$ cheaper and there are some 56,000 of which $60 \%$ are by employers, also SMEs. See, e.g., Commissie Evaluatie Risicoverevening ZVW (2012). 
1986), within firms (Fitzenberger et al. 2015), and across industries (Gangl 2003; Bachmann and Burda 2010). In part, the low mobility may be a result of Germany's "orderly" educational system, which sets people on a highly predictable career path. Linking social security entitlements to job tenure is then perhaps a consequence of, as much as a cause for, immobility. Under such circumstances, any portability reform would have to be accompanied by reforms in the educational system to be effective.

Furthermore, it should be evident that complexity and opacity in social security systems make both beneficiaries and employees risk averse, reducing the attractiveness of any nonstandard labor market offerings. Such corrosion is perhaps inevitable over time, but as with the tax system, an occasional redesign of the social security system from the ground up could enhance transparency and neutrality. One form that such a reboot could take in European welfare states would be the introduction of a universal negative income tax system. Such a reform provides the system with an unconditional floor on which policymakers can build more detailed and complicated structures.

Proposal 30: Investigate the possibility of establishing a modest but unconditional floor in the social security system through a negative income tax system.

The main benefit of a negative income tax scheme would be to reduce the need to reform current welfare state arrangements to create access for selfemployed and freelance workers who, though hard to classify, will make up a growing share of the labor force in an entrepreneurial society (Noorderhaven et al. 2004; Hatfield 2015). Once more, this reform would constitute a fundamental paradigm shift in providing social security benefits and will involve careful long-term planning, small scale experimentation, and step-by-step implementation to ensure success. But once a basic level for a decent living is provided collectively, other features of the system — unemployment benefits, disability and sickness insurance, child care, educational allowances, and pension schemes-go from being peoples' only source of income and support to being add-ons that can arguably be left (more) to private or collective initiatives and self-insurance. With the universal basic level to fall back on, entrepreneurs and self-employed individuals will not need expensive insurance for temporary involuntary unemployment or illness. As such, the guarantee enables them to compete on quality and not on their ability to self-insure such risks. This may be helpful both for $\mathrm{R} \& \mathrm{D}$ workers wishing to start innovative high-tech ventures and for the growing army of everyday entrepreneurs that are important in an entrepreneurial society (Welter et al. 2017). 
That said, the results from the Finnish basic income experiment have been mixed. While the experiment seems to have made participants happier and less stressed, it did not achieve the intended effect of giving people more incentives to find work than the traditional system (Meyer 2019). More generally, there is a risk that a negative income tax may encourage activity in the informal economy, which, as mentioned, is already a major concern in Southern and Eastern Europe. Maintaining a low floor will also become increasingly difficult as time goes by and politicians are tempted to try to buy votes. Overall, such a system is probably only viable in countries with low corruption and high tax compliance; only then will the institutional environment be robust against the corrosive effects and the inevitable incentives to game the system.

Investing in the ability of people to rejoin the labor market soon after losing a job is better than income insurance in case of joblessness. To prepare people for the new labor market, an efficient flexicurity model must encourage the retraining of redundant workers, preferably in the dual sense that training should be a right and a mandatory responsibility.

Proposal 31: Establish or strengthen retraining programs to prepare workers for new occupations.

The proposal falls under the broader heading of active labor market policies commonly advocated for and implemented throughout the EU (European Commission 2018b). Job creation and destruction are relatively high in a country such as the UK, and small firms are disproportionately responsible for this. The implication is that employees in a more entrepreneurial society need to be equipped with the skills necessary to switch jobs and employers (Hijzen et al. 2010). As neither government agencies nor private providers have proven effective in retraining workers, local and regional governments should think carefully about how to organize these programs. Because training works best when people are motivated (Fouarge et al. 2013), the impact of such programs is probably the greatest if trainers can motivate, convince, and help people to help themselves.

\subsection{Summary}

The labor market allocates scarce labor resources in the economy while providing most people with their main source of income. Because the administrative burden and the insurance of social risks by employers fall 
disproportionately on small and young firms, reforms should aim for moderate universal social insurance and transparent and straightforward systems. The full portability of entitlements and flexible employment contracts would create a more level playing field in the competition for labor, given that young, innovative firms can seldom offer long and secure tenure. Flexibility measures would also be justifiable when they balance the collective interests of social security and fair income distribution with the private interest of fair compensation for merit and the efficient matching of people to jobs.

Table 5.1 provides a summary of our proposals regarding labor markets and social security, specifying the level in the governance hierarchy that should make the necessary decisions. The institutions in this area are typically highly country-specific, path-dependent, and complementary, meaning that policymakers must carefully fit them to local contexts when implementing reforms. The competencies for doing so are limited at the EU level, but this is probably not to be lamented; the diverse varieties of capitalism in Europe mean that the same reforms can be expected to work out quite differently in different contexts, and reforms are more urgent in some member states than in others.

Although the articles in the various treaties are not intended to give the Union a say over the level, shape, or form of member states' labor market institutions, the EU has many soft instruments available to coordinate and inform. As the institutional arrangements in the labor market and social security operate at the national level, there is also little scope for regional and local policymaking in this area, even if some member states have at times decentralized the execution of the programs. For these reasons, we address most of the proposals primarily at the member state level, where reforms following our general principles need careful fitting to the specific national context to achieve their aims.

Proposals on social security and labor market regulation all aim to mobilize Europe's most knowledgeable and valuable employees. The portability of social security entitlements across jobs, sectors, and labor market statuses will eliminate the lock-in of skilled labor in gilded jobs and reduce the barriers for employers. As such, they would create a level playing field for start-ups on the demand side and for marginalized groups in the labor market on the supply side. Creating a level playing field will also entail forcing the self-employed to join collective social insurance, e.g., for pension and health costs. This will make growth in Europe more inclusive, equitable, and innovation driven. 
Table 5.1 Summary of proposals regarding labor markets and social security, specifying the level in the governance hierarchy where the necessary decisions should be made

\begin{tabular}{|c|c|c|c|c|}
\hline No. & Principle(s) & Policy area & Proposal & $\begin{array}{l}\text { Policy } \\
\text { level }^{a}\end{array}$ \\
\hline 23 & $\begin{array}{l}\text { Neutrality and } \\
\text { transparency }\end{array}$ & $\begin{array}{l}\text { Employment } \\
\text { protection }\end{array}$ & $\begin{array}{l}\text { Relax the stringency of employment } \\
\text { protection legislation for permanent } \\
\text { contracts. }\end{array}$ & MS \\
\hline 24 & Neutrality & $\begin{array}{l}\text { Employment } \\
\text { protection }\end{array}$ & $\begin{array}{l}\text { Allow for more flexibility in working } \\
\text { hours by reconsidering overly } \\
\text { stringent minimum requirements for } \\
\text { daily and weekly working hours, } \\
\text { holidays, irregular hours, and } \\
\text { overtime. }\end{array}$ & EU \\
\hline 25 & $\begin{array}{l}\text { Neutrality and } \\
\text { transparency }\end{array}$ & $\begin{array}{l}\text { Employment } \\
\text { protection }\end{array}$ & $\begin{array}{l}\text { Lift the legal enforceability of } \\
\text { confidentiality agreements between } \\
\text { employers and their employees. }\end{array}$ & EU, MS \\
\hline 26 & Neutrality & Social security & $\begin{array}{l}\text { Guarantee equal access to welfare } \\
\text { state arrangements for all, } \\
\text { regardless of tenure in a specific job } \\
\text { or labor market status. }\end{array}$ & EU, MS \\
\hline 27 & $\begin{array}{l}\text { Neutrality and } \\
\text { transparency }\end{array}$ & Social security & $\begin{array}{l}\text { Carefully consider the impact of } \\
\text { flexicurity reforms on young firms } \\
\text { and do not force them to take on } \\
\text { excessive risks and burdens. }\end{array}$ & MS \\
\hline 28 & $\begin{array}{l}\text { Transparency } \\
\text { and justifiability }\end{array}$ & Social security & $\begin{array}{l}\text { Introduce mandatory universal } \\
\text { insurance to cover healthcare costs, } \\
\text { old age, and disability. }\end{array}$ & MS \\
\hline 29 & Neutrality & Social security & $\begin{array}{l}\text { Ensure full portability of social } \\
\text { security entitlements by making } \\
\text { them independent of tenure at a } \\
\text { specific employer. }\end{array}$ & EU, MS \\
\hline 30 & $\begin{array}{l}\text { Neutrality and } \\
\text { moderation }\end{array}$ & Social security & $\begin{array}{l}\text { Investigate the possibility of } \\
\text { establishing a modest but } \\
\text { unconditional floor in the social } \\
\text { security system through a negative } \\
\text { income tax system. }\end{array}$ & EU, MS \\
\hline 31 & Neutrality & $\begin{array}{l}\text { Active labor } \\
\text { market policy }\end{array}$ & $\begin{array}{l}\text { Establish or strengthen training } \\
\text { programs to prepare workers for } \\
\text { new occupations. }\end{array}$ & $\begin{array}{l}\text { EU, MS, } \\
\text { REG, } \\
\text { LOC }\end{array}$ \\
\hline
\end{tabular}

aEU federal level, MS member state level, REG regional government level, LOC local/ municipal level 
Open Access This chapter is licensed under the terms of the Creative Commons Attribution 4.0 International License (http://creativecommons.org/licenses/by/4.0/), which permits use, sharing, adaptation, distribution and reproduction in any medium or format, as long as you give appropriate credit to the original author(s) and the source, provide a link to the Creative Commons licence and indicate if changes were made.

The images or other third party material in this chapter are included in the chapter's Creative Commons licence, unless indicated otherwise in a credit line to the material. If material is not included in the chapter's Creative Commons licence and your intended use is not permitted by statutory regulation or exceeds the permitted use, you will need to obtain permission directly from the copyright holder. 